\title{
Plant Growth Regulators and Strawberry Production
}

\author{
Saurabh K. Singh, Ashvin A. Bhople, Paresh P. Kullarkar*, \\ Nikhil Bhople and Ajay Jumale
}

Department of Horticulture, School of Agriculture, Lovely Professional University, Phagwara, Punjab-144 411, India

*Corresponding author

\begin{tabular}{|c|c|}
\hline & A B S T R A C T \\
\hline & \multirow{6}{*}{$\begin{array}{l}\text { Strawberry is an attractive, tasty, luscious and nutritious fruit grown in temperate and } \\
\text { subtropical climate. Plant growth regulators (PGRs) play important role in strawberry } \\
\text { production which regulate plant growth, flowering and increase the yield of crops. In } \\
\text { recent years, the interest in strawberry production has increased rapidly because of high } \\
\text { price value and more demand. Yield increase in strawberry crops has been obtained } \\
\text { through improved varieties, efficient management of fertilizers and various agronomic } \\
\text { practices. Growth regulating chemicals are also becoming important in strawberry } \\
\text { production for the modification of their vegetative growth, flowering, and fruiting which } \\
\text { affect total yield and fruit quality. A structured review of the effect of plant growth } \\
\text { regulators on growth, flowering, yield and shelf life, was prepared. Effect of different } \\
\text { PGRs, alone and their combinations were explored. Auxins and gibberellins were } \\
\text { identified as potent PGRs for improving growth, flowering, yield and post-harvest life } \\
\text { parameters. Areas of interest where further research is needed include evaluating the effect } \\
\text { of different combination and time of application of PGR and difference in varietal } \\
\text { response with the growth regulators treatment. Hence, there is further need to evaluate the } \\
\text { effect of growth regulators on strawberry. }\end{array}$} \\
\hline Keywords & \\
\hline $\begin{array}{l}\text { Strawberry, PGRs, } \\
\text { Growth, Flowering, } \\
\text { Yield }\end{array}$ & \\
\hline Article Info & \\
\hline $\begin{array}{l}\text { Accepted: } \\
\text { 12 July } 2018 \\
\text { Available Online: } \\
10 \text { August } 2018\end{array}$ & \\
\hline & \\
\hline
\end{tabular}

\section{Introduction}

Plant growth regulators used to alter the growth of a plant or plant part. Basically, there are 5 types of growth regulators viz. (A) growth promotors like auxins (indole acetic acid (IAA), indole butyric acid (IBA), naphthalene acetic acid (NAA), 2-4-dichloro phenoxy acetic acid (2, 4-D), gibberellins (Gibberellic acid or GA), cytokinins (kinetin, zeatin) and (B) growth inhibitors/retardants like abscisic acid (ABA), ethylene (Fishel, 2006; Harms and Oplinger, 1988). Generally, growth regulators application has been practiced to increase production and quality of fruit crops. Effect of PGRs has been investigated extensively in strawberry. They regulate the plant growth and increase the yield of strawberry (Dwivedi et al., 1999; Kumar et al., 2012a, b; Khunte et al., 2014). During recent years, the interest in strawberry production has increased rapidly because of its better generic diversity, heterozygosity and broader range of its environmental adaptation of improved varieties, off-season production (Peng, et al., 2015; Hancock, et al., 2000; 
Durner, 2018). Yield of the strawberry crop can be increased through improved varieties, efficient use of chemicals fertilizers and various agronomic practices. Besides, growth regulating chemicals are also becoming important in the strawberry for the modification of their vegetative growth, flowering, and fruiting affecting total yield and also quality (Vishal et al., 2016; Palai et al., 2016).

\section{Growth parameter}

PGRs have been found useful in improving growth parameters of strawberry. Palei et al., (2016) reported that maximum plant spread $(35.7 \mathrm{~cm})$, petiole length $(13.2 \mathrm{~cm})$, number of leaves (20.8/plant) and runners (3.2/plant) was obtained in strawberry cv. Chandler with GA3 @ 100ppm. Vishal et al., (2016) observed that GA3 (125ppm) gives maximum plant height $(22.39 \mathrm{~cm})$, length of trifoliate leaves $(11.64 \mathrm{~cm})$, number of leaves per plant (28.33), plant spread $(29.70 \mathrm{~cm})$, breadth of trifoliate leaves $(15.86 \mathrm{~cm})$ and runners per plant (5.87) in strawberry cv. Sujata. Rajbhar et al., (2015) reported that GA3 (100 ppm) resulted higher yield in Chandler cv. of strawberry. Saima et al., (2014) reported that application of GA3 $75 \mathrm{mg} / \mathrm{l}$ resulted maximum petiole length (25.53), leaf area $\left(136.30 \mathrm{~cm}^{2}\right)$, number of leaf per plant (23.00). Swamishekhar (2013) found that rate of photosynthesis was significantly affected by different concentrations of growth regulator treatments. Maximum photosynthetic rate $\left(8.31 \mu \mathrm{mole} / \mathrm{m}^{2} / \mathrm{sec}\right.$.) was registered in plants treated with CPPU 6 ppm +GA3 50 ppm treatment followed by CPPU $4 \mathrm{ppm}+\mathrm{GA} 3$ $50 \mathrm{ppm}, \mathrm{GA} 375 \mathrm{ppm}$ and CPPU 2ppm + GA3 $50 \mathrm{ppm}$ treatments, while the minimum photosynthesis (3.39 $\mu \mathrm{mole} / \mathrm{m}^{2} / \mathrm{sec}$.) was recorded in control. Asadi et al., (2013) assessed effect of different concentration of GA3 $(25,50,100 \mathrm{ppm})$ in strawberry cultivar Gaviota in which GA3 (50ppm) was best for proper growth and yield of strawberry. Singh and Singh (2009) reported that strawberry cultivar Sweet Charlie showed maximum total biomass $(42.02 \mathrm{gm} /$ plant $)$, plant height $(27.33 \mathrm{~cm})$ and chlorophyll at $50 \% \mathrm{~N}$ standard dose and GA3 (100ppm). While, dual inoculation with $75 \% \mathrm{~N}$ and 100ppm BA gives maximum number of crowns per plant (5.87), leaves (26.92/plant) and leaf area $\left(123.29 \mathrm{~cm}^{2}\right)$. Perez et al., (2009) observed the highest leaf number, crown number and the number of flowers in plants of the strawberry cultivar Chandler treated with $20 \mathrm{mg}$ per litre of gibberellic acid. Hytonen et al., (2009) concluded that GA3 is needed for runner initiation in strawberry and the inhibition of GA biosynthesis leads to the formation of crown branches. GA3 applied at a concentration of $1.0-2.0 \mathrm{mg}$ dm-1 significantly increased the number of axillary shoots (mainly crown shoots), whereas under higher (5.0- $10.0 \mathrm{mg} \mathrm{dm}^{-3}$ ) doses it stimulated the development of runners as reported by Litwinczuk et al., (2009). Mir et al., (2004) observed that application of GA3 significantly increased the number of runners as compared to NAA and control.

Tripathi and Shukla (2006) also obtained higher plant height $(20-39 \mathrm{~cm})$ and number of leaves (18.09) with GA3 application at 100 ppm over the effect of NAA, GA3, CCC and BA in strawberry cultivar Chandler. Dwivedi et al., (1999) evaluated the effect of Gibberellic acid (25, 50 and $100 \mathrm{ppm})$, Alar (250, 500 and $1000 \mathrm{ppm})$, Ethrel (250, 500 and $1000 \mathrm{ppm}$ ), Morphactin (25, 50 and 100ppm) and Cycocel (500, 1000 and 2000 ppm) on strawberry cultivars 'Senga Sengana' and 'Missionary'. GA3 (50 ppm) recorded effective plant growth regulator for improving leaf number, petiole length and number of runners in strawberry. GA3 $0.08 \%$ increases $22 \%$ runner per plant and CCC $1.2 \%$ increases $10 \%$ number of runners per plant in strawberry cv. Guedes (Pankov, 1992). 


\section{Floweing, fruit set and yield parameter}

PGRs play important role in flowering and fruiting of strawberry. Palei et al., (2016) c carried out an experiment on strawberry $\mathrm{Cv}$. Chandler with different type of PGRs GA3 $(25,50,100 \mathrm{ppm})$, IAA $(25,50,100 \mathrm{ppm})$ and NAA $(25,50,100 \mathrm{ppm})$. Higher number of flowers per plant (24.1) and number of fruit per plant (22.5) was obtained from NAA (100ppm) over the other treatments. Rajbhar et al., (2015) reported that application of GA3 100ppm + vermicompost @100q/ha resulted higher yield in strawberry cv. Chandler. Saima et al., (2014) recorded that application of GA3 $75 \mathrm{mg} / 1$ resulted higher yield, flower per plant and number of berries. Asadi et al., (2013) recorded more yield in strawberry cultivar Gaviota with GA3 (50ppm).

Prasad et al., (2012) carried out an experiment with strawberry cultivar Douglas with different type of mulching materials and (straw mulch, black polythene mulch, transparent mulch, PGRs (GA3 (25, 50, $100 \mathrm{ppm})$ and NAA (10, 20, 40ppm). Maximum yield (349.05g/plant), plant height $(23.20 \mathrm{~cm})$, number of flowers $(38.25 /$ plant $)$, early harvesting (81.61days), maximum costbenefit ratio $(1.62 \%)$ was observed with GA3 $100 \mathrm{ppm}+$ black polythene mulch. Kumar et al., (2012) evaluated effect different type of PGRs viz. GA3 (25, 50,75ppm), cycocel (300, $600,900 \mathrm{ppm})$ and triacotanol $(1.25,2.5$, $5 \mathrm{ppm}$ ) on strawberry cv. Sweet Charlie. Result showed that higher yield (376.69g/plant), number of fruits (23.31), and fruit yield $(27.90 \mathrm{q} / \mathrm{ha})$, length: diameter ratio of fruit (1.50) was recorded with triacotanol 5ppm. Al-Madhagi et al., (2012) reported increased number of fruits per plant with the application of GA3 at $50 \mathrm{ppm}$ in strawberry cultivar Camarosa. Uddin et al., (2012) recorded the maximum number of flowers (28.7/plant), fruits (25.9/plant) and yield (336.6 g/plant) in strawberry plant treated with GA3 75 ppm which was closely followed GA3 $100 \mathrm{ppm}$ and minimum (21.1, 19.6 and $248.9 \mathrm{~g} / \mathrm{plant}$, respectively) in control. Singh and Singh (2009) conducted an experiment on strawberry cultivar Sweet Charlie with different type of PGRs and bio fertilizers. Result showed that maximum total biomass (42.02gm/plant), and chlorophyll was obtained from $50 \% \mathrm{~N}$ standard dose and sprayed with GA3 100ppm. Dual inoculation with $75 \% \mathrm{~N}$ and 100ppm BA gives maximum Yield and fruit set was maximum in combination of GA3 100ppm $+50 \% \mathrm{~N}+$ azotobactor + azospirillium application.

\section{Fruit Quality}

Rajbhar et al., (2015) found that GA3 $100 \mathrm{ppm}+$ vermicompost @ 100q/ha resulted more TSS (10.68 ${ }^{\circ}$ Brix) in strawberry var. Douglas. Kumar et al., (2012) recorded the maximum fruit length-diameter ratio (1.28 $\mathrm{cm})$, juice content $(87.35 \%)$ and TSS (9.07 $\%)$ with GA3 (30 ppm) while maximum ascorbic acid (63.03 mg/100 g) and acidity $(0.75 \%)$ with GA3 (90 ppm). Uddin et al., (2012) recorded the maximum fruit length $(32.7 \mathrm{~mm})$, diameter $(25.0 \mathrm{~mm})$, fruit weight $(13.2 \mathrm{~g})$ and TSS $(4.7 \%)$ in strawberry plants treated with GA3 $75 \mathrm{ppm}$ as compared to control (no GA3).

Kumar et al., (2012a) evaluated effect different type of PGRs viz. GA3 (25, $50,75 \mathrm{ppm})$, cycocel $(300,600,900 \mathrm{ppm})$ and triacotanol $(1.25,2.5,5 \mathrm{ppm})$ on strawberry cv. Sweet Charlie. Result showed higher $\mathrm{pH}$ value (3.69), and specific gravity (1.28\%) was recorded with triacotanol 5ppm. Cycocel 900ppm gives highest vitamin $\mathrm{C}$ $(55 \mathrm{mg} / 100 \mathrm{gm})$, total sugar $(9.40 \%)$, TS $(9.40 \%)$, TSS (9.63degree Brix), juice content (93.66\%). Sharma and Singh (2009) obtained highest juice content $(74.8 \%)$ and ascorbic acid content $(50.4 \mathrm{mg} / 100 \mathrm{~g})$ in strawberry cultivar Chandler when plants were twice 
sprayed with GA3 (75 ppm) during midNovember and mid -February. Roussos et al., (2009) observed that anthocyanin content in strawberry fruit increased significantly when the plants were treated with GA3.

\section{Shelf life of fruits}

Pre and post-harvest applications of PGRs improves fruit quality, helps to delay the senescence in storage and improves the shelf life of strawberry (Singh et al., 2017; Jain and Singh, 2004). Minz (2010) observed that GA3 + black polythene mulch was best to extend the shelf life of strawberry fruits for 2.48 days under ambient conditions. Jain and Singh (2004) conducted an experiment to extend the shelf life of 'Chandler' strawberry (Fragaria $\times$ ananassa) fruits with four plant growth regulators (NAA, TIBA, gibberellic acid and 2,4-D) and 2 calcium salts (calcium nitrate and $\mathrm{CaCl} 2$ ). The pre-harvest foliar spray of the crop with GA3, NAA, 2,4-D and calcium nitrate extended the shelf life and helped in developing quality ripe fruits in terms of retaining high reducing sugars, minimum cumulative physiological loss in weight and higher vitamin $\mathrm{C}$ retention.

Pre-harvest (14 days prior harvesting) spray with 25 ppm GA3 was the best treatment, followed by 10 ppm 2,4- D and 1\% calcium nitrate, which not only extended the shelf life (up to 9 days) but also reduced the postharvest decay losses (1.55\%) and minimized the cumulative physiological loss in weight $(7.26 \%)$ due to moisture loss and degradative metabolism during ripening without adversely affecting the quality. The pre-harvest treatment with NAA $25 \mathrm{ppm}$ favoured the higher vitamin $C(49.30 \mathrm{mg} / 100$ g pulp) content during storage.

The literature available revealed that plant growth regulators give an instant impact on crop growth. Latest scientific findings showed that GA3 is an effective PGR for improving growth, yield, quality and shelf life of strawberry. More research is needed to evaluate the effect of different combination and time of application of PGR on strawberry. Hence, there is need to evaluated effect of growth regulators on different varieties of strawberry.

\section{References}

Acuna-Maldonado L.E. and Pritts M. P. 2008. Carbon and Nitrogen reserves in perennial strawberry affect plant growth and yield. Journal of the American Society for Horticultural Science, 133 (6): 735-742.

Adam D., Elfwing D.C. and Chandler C.K. 1996. Benzyl Adenine and Gibberellic acid increase runner production in day neutral strawberries. Horticulture science, 31(7): 1190-1194.

Al-Madhagi Isam Abdulbaset Haidar, $\mathrm{H}$. Ahmad Aziz bin, Zain Abdullah $\mathrm{M}$ and Yusoff Wan Abdullah bin. 2012. The influence of exogenous hormone on the flowering and fruiting of strawberry (Fragaria x ananassa Duch.). Journal of Biology, Agriculture and Healthcare, 2(4), 46-52.

Asadi1 Z., Jafarpour M., Golparvar A. R. and Mohammadkhani A. 2013. Effect of GA3 application on fruit yield, flowering and vegetative characteristics on early yield of strawberry cv. Gaviota. International Journal of Agriculture and Crop Sciences, 5-15/1716-1718.

Cameron J.S., Hancock J. F. and NourseT. M. 1985.The field performance of strawberry nursery stock produced originally from runners or micropropagation. Advance Strawberry Production, 4: 56- 58.

Durner, E. F. 2018. Long-day and nitrogen conditioning of 'Albion' strawberry (Fragaria $\mathrm{X}$ ananassa Duch.) enhances off-season field production. The Journal 
of Horticultural Science and Biotechnology, 93(3), 296-305.

Dwivedi M. P., Negi K. S., Jindal K. K. and Rana H. S. 1999. Effect of bioregulators on vegetative growth of strawberry. Scientific Horticulture, 6: 79-84.

Fishel, F. M. 2006. Plant growth regulators. Document PI-139, Pesticide Information Office, Florida Cooperative Extension Service, Institute of Food and Agricultural Sciences, University of Florida.

Garner L., Klein G., Zheng Y., Khuong T. and Lovatt C. J. 2009. Response of evergreen perennial tree crops to gibberellic acid is crop load-dependent: II. GA3 increases yield and fruit size of 'Hass' avocado only in the on-crop year of an alternate bearing orchard. Journal of the American Society for Horticultural Science, 133: 310.

Haidar A. I. A., Zain S. M., Bin A. A., Zain A. M. and Bin Y.W. A. 2012.The influence of exogenous hormone on the flowering and fruiting of strawberry (Fragaria $x$ ananassa Duch.). Journal of Biology, Agriculture and Healthcare, 2(4): 46-52.

Hancock, J. F., Hokanson, S. C., Finn, C. E., and Hummer, K. E. 2000. Introducing a supercore collection of wild octoploid strawberries. In IV International Strawberry Symposium 567 (pp. 77-79).

Harms, C. L., and Oplinger, E. S. 1988. Plant growth regulators: their use in crop production. Purdue University, Cooperative Extension Service.

Hytönen, T., Elomaa, P., Moritz, T., and Junttila, O. 2009. Gibberellin mediates daylength-controlled differentiation of vegetative meristems in strawberry (Fragariax ananassa Duch). BMC Plant Biology, 9(1), 18.

Kender W.J., Carpenter S. and Braun J.W. 1971. Runner formation in ever bearing strawberry as influenced by growthpromoting and inhibiting substances. Annual Botany, 35:1045- 52.

Khan M. M. A., Champa G., Firoz M., Siddiqui M. H., Naeem M. and Khan M. N. 2006.
Effect of Gibberellic Acid Spray on Performance of Tomato. Turkish Journal of Biology, 30: 11-16.

Khunte S. D., Kumar A., Kumar V., Singh S. and Saravanan S. 2014. Effect of plant growth regulators and organic manure on physico-chemical properties of strawberry (Fragaria $x$ ananassa Duch.) cv. Chandler. International Journal of Scientific Research and Education, 2(7): 158-165.

Kumar R., Bakshi M. and Singh B.D. 2012b. Influence of plant growth regulator on growth, yield and quality of strawberry (Fragaria $x$ ananassa Duch.) Under U.P. Subtropics, the Asian journal of Horticulture, 7(2):434-436.

Kumar R., Bakshi P., Srivastava J.N. and Sravanan S. 2012a. Influence of plant growth regulators on growth, yield and quality of strawberry (Fragaria $x$ ananassa Duch.) cv. Sweet Charlie. The Asian Journal of Horticulture, 7(1): 4043.

Kumar, R., Sharma, N., Jamwal, M., Sharma, R. M., Singh, D. B., and Parmar, A. M. 2012. Production and economic studies of PBRs treated strawberry (Frageria $\mathrm{x}$ ananassa Duch.) cv. Sweet Charlie. American-Eurasian Journal of Agriculture and Environmental Science, 12(12), 1.

Litwińczuk, W., Okołotkiewicz, E. And Matyaszek, I. 2009. Development of in vitro shoot cultures of strawberry (Fragaria $\times$ ananassa Duch.) 'Senga Sengana' and 'Elsanta' under the influence of high doses of gibberellic acid. Folia Horticulturae, 21(2), 43-52.

Minz, M. 2010. Effect of mulching and pgr on growth, yield and quality of strawberry (Fragaria ananassa Duch.) cv. Douglas (Doctoral dissertation, Birsa Agricultural University, Kanke, Ranchi, Jharkhand).

Mir M. M., Barche S. and Singh D. B. 2004. Effect of plant growth regulators on growth, yield and quality of strawberry (Fragaria $x$ ananassa Duch.) cv. Sweet 
Charlie. Applied Biological Research, 6(1/2): 48-51.

MisratiaK. M., Ismail M. R., Hakim M. A., Mohamed H. M. and Puteh A. 2013. Effect of salinity and alleviating role of gibberellic acid (GA3) for improving the morphological, physiological and yield traits of rice varieties. Australian Journal of Crop Science, 7(11): 1682-1692.

Nor S. S., Razifah M. R., Mamat A. S. and Adzemi M. A. 2014. Application of gibberellic acid (GA3) in stem cutting of dragon fruit (Hylocereus Polyrhizus): effects on fruit quality and yield at harvest. Journal of Biology, Agriculture and Healthcare, 4(21): 51- 55.

Ozguven A., Yilmaz C., Hietaranta T. and Linna M. 2000. The effect of GA3 and promalin on fruit quality of strawberry. ActaHorticulturae, 548: 216-219.

Palei S., Das A., Sahoo1 A. K., Dash D. K. and Swain S. 2016. Influence of plant growth regulators on strawberry (fragaria $\times$ ananassa) cv. Chandler under odisha condition. International Journal of Recent Scientific Research, 7 (4): 9945-9948.

Palei S., Das A.K., Sahoo A.K., Dash A.K. and Swain S. 2016. Influence of plant growth regulators on strawberry Fragaria $x$ ananassa $\mathrm{Cv}$. Chandler) Under Odisha conditions. International journal of Recent Scientific Research, 7(4); 9945 9948.

Pankov C V. 1992. Effect of growth regulators on plants production of strawberry mother plants. Scientia Horticulturae. 52: 157161.

Peng, M., Zong, X., Wang, C., and Meng, F. 2015. Genetic diversity of strawberry (Fragaria ananassa Duch.) from the Motuo County of the Tibet Plateau determined by AFLP markers. Biotechnology and Biotechnological Equipment, 29(5), 876-881.

Perez D. C. M., Mogollon N., Ojeda M., Gimenez A. and Colmenares C. 2009. The effect of gibberelic acid on the growth and flowering of strawberry (Fragaria $x$ ananassa Duch.) 'Chandler' vitro plants. Acta Horticulturae, 842: 793-796.

Prasad M., Minz M., Kumar R. and Das B. 2012. Effect of Mulching and PGRs on growth, yield and quality of strawberry cv. Douglas. Internet Journal Agriculture Science, 16 (1): 4415.

Pritts M. and A. Dale. 1989. Dayneutral strawberry production guide. Available from

Strawberry\%20Production\%20Guide.pdf [updated 1989, cited March 2012].

Pritts M.P., Posner G.S. and Worden K.A. 1986. Effects of 6-BA application on growth and development of 'Tristar', a strong day-neutral strawberry. Horticulture Science, 21:1421-1423.

Qureshi K. M., Chughtai S., Qureshi U. S. and Abbasi N. A. 2013. Impact of exogenous application of salt and growth regulators on growth and yield of strawberry. Pakistan Journal of Botany, 45(4): 11791185.

Rajbhar Y.P. Singh B. Singh G. Singh D.K and Kumar M. 2015. Studies on the effect of growth regulator and vermicompost on growth and yield of different cultivers of strawberry (Fragaria x ananassa Duch). The Asian Journal of Horticulture, 10(2): 222-231.

Rana R. K. 2001. Studies on the influence of nitrogen fixers and plant bioregulators on growth, yield and fruit quality of strawberry cv. Chandler. Ph.D. Thesis, Dr. Y. S. Parmar University of Horticulture and Forestry, Solan, (HP). Reid, J.H. 1983. Practical growth regulator effects on strawberry plants-a review. Crop Research, 23:113-120.

Reid J.H. 1983. Practical growth regulator effects on strawberry plants-a review. Crop Research, 23: 113-120.

Roussos P. A, Denaxa N. K. and Damvakaris T. 2009. Strawberry fruit quality attributes after application of plants growth stimulating compound. Scientia Horticulturae. 119(2): 138-146.

Saima Z., Sharma A., Umar I. and Wali V. K. 2014. Effect of plant bio- regulator on 
vegetative growth, yield and quality of strawberry cv. Chandler. Academic journals, 9(22): 1694-1699.

Scott D.H., Galletta G.J. and Swartz H.J. 1985. Tissue culture as an aid in the propagation of 'Tribute' ever bearing strawberry. Advance Strawberry Production, 4: 5960.

Shahin M. F., Fawzi M. I. F. and Kandil E. A. 2010. Influence of foliar application of some nutrient (Fertifol Misr) and gibberellic acid on fruit set, yield, fruit quality and leaf composition of 'Anna' apple trees grown in sandy soil. Journal of American Science, 6(12): 202- 208.

Sharma R. R. and Singh R. 2009. Gibberellic acid influences the production of malformed and button berries and fruit yield and quality in strawberry (Fragaria $\times$ ananassa Duch.). Scientia Horticulture, 119(4): 430- 433.

Singh K.S. and Saravanan1S. 2012. Effect of bio-fertilizers and micronutrients on yield and quality of strawberry (Fragaria $x$ ananassa Duch) cv. Chandler, The Asian Journal of Horticulture, 7(2): 533-536.

Singh O. P. and Phogat K. P. S. 1983. Effect of plant growth regulators on vegetative growth, yield and quality of strawberry (Fragaria sp.). Progressive Horticulture, 15: 64- 68.

Singh V. K. and Tripathi V. K. 2010. Efficacy of GA3, boric acid and zinc sulphate on growth, flowering, yield and quality of strawberry cv. Chandler. Progressive Agriculture, 10(2): 345-348.

Singh, A. and Singh, J.N. 2009. Effect of bioregulators on growth, yield and nutrient status of strawberry cv. Sweet Charlie. Indian Journal of Horticulture, 66(2): 220-224.

Singh, K., Sharma, M. and Singh, S. K. 2017. Effect of plant growth regulators on fruit yield and quality of guava (Psidium guajava) cv. Allahabad Safeda. Journal of Pure and Applied Microbiology, 11(2), 1149-1155.

Swamyshekhar R. 2013. Effect of growth regulators on the growth, yield and quality of strawberry (Fragaria $x$ ananassa Duch.) cv. Chandler. M. Sc. Thesis. Dr Y S Parmar University of Horticulture and Forestry, Nauni, Solan, H P. 165.

Tripathi, V. K. and Shukla, P. K. 2006. Effect of plant bioregulator on growth, yield and quality of strawberry cv. Chandar. J. Asian Hort, 2(4), 260.

Uddin, A. J., Hossan, M. J., Islam, M. S., Ahsan, M. K. and Mehraj, H. 2012. Strawberry growth and yield responses to gibberellic acid concentrations. J. Expt. Biosci, 3, 51-56.

Vishal V. C., Thippesha D., Chethana K., Maheshgowda B. M., Veeresha B. G. And Basavraj A. K. 2016. Effect of Various Growth Regulators on Vegetative parameters of strawberry (Fragaria $x$ ananassa Duch.) Cv. Sujatha Research Journal Chemical and Environmentel Sciences, 4 (4): 68-71.

Waithaka K. and Dana M. N. 1978. Effects of growth substances on strawberry growth. Journal of the American Society for Horticultural Science, 103: 627-628.

\section{How to cite this article:}

Saurabh K. Singh, Ashvin A. Bhople, Paresh P. Kullarkar, Nikhil Bhople and Ajay Jumale. 2018. Plant Growth Regulators and Strawberry Production. Int.J.Curr.Microbiol.App.Sci. 7(08): 24132419. doi: https://doi.org/10.20546/ijcmas.2018.708.243 